\title{
Partnerships in Teacher Education - Going Beyond the Rhetoric, with Reference to the Norwegian Context
}

KARI SMITH ${ }^{1}$

$\approx$ Teacher education plays a central role in education and relates to various stakeholders of education. Currently, teacher education is not perceived as the sole responsibility of higher education institutions, and they are expected to work closely together with other partners. In this paper, the concept of 'partnership' is defined and mutual benefits and challenges in partnerships with disciplines and institutions beyond teacher education programs are briefly discussed. Issues related to partnerships with students are addressed, and the last part of the paper discusses the partnership between teacher education and the practice field with examples from Norway. Three models illustrating such partnerships are described. The central argument of the paper is that partnerships in teacher education need to go beyond rhetoric.

Keywords: partnership, partnership with students, school-university collaboration, the third space 


\section{Partnerstva v izobraževanju učiteljev - onkraj retorike, s poudarkom na norveškem kontekstu}

KARI SMITH

$\propto$ Izobraževanje učiteljev v izobraževanju igra osrednjo vlogo in se nanaša na različne akterje. Trenutno je izobraževanje učiteljev dojeto kot odgovornost visokošolskih ustanov; od njih se pričakuje, da tesno sodelujejo z drugimi partnerji. V tem prispevku je definiran koncept "partnerstva«. Prav tako na kratko razpravljamo o skupnih prednostih in izzivih partnerstva $z$ disciplinami in ustanovami onkraj programov za izobraževanje učiteljev. Naslavljamo tudi vprašanja partnerstva $s$ študenti, v zadnjem delu prispevka pa razpravljamo o partnerstvu med izobraževanjem učiteljev in prakso na norveških primerih. Opisani so trije takšni modeli. Osrednji argument prispevka je, da morajo partnerstva v izobraževanju učiteljev iti onkraj retorike.

Ključne besede: partnerstvo, partnerstvo s študenti, sodelovanje šoluniverz, tretji prostor 
Coming together is a beginning,

Keeping together is progress, working together is success.

(Henry Ford)

\section{Introduction}

Teachers matter (OECD, 2005), teacher education matters (EU Commission, 2013), and school matters (Donaldson 2011, 2015). Education matters, so that the children of today and of tomorrow are well prepared to develop our respective nations and the global society to serve as constructive contexts for humanity. The responsibility for education lies with various stakeholders, policy makers, researchers and teacher educators, teachers, and parents. Teacher education is placed in the middle of the many complex relationships among the various stakeholders, as it is the agent for executing decisions made by policymakers in preparing teachers, who again prepare the citizens of future generations. Thus, teacher education carries an enormous responsibility, and it cannot do so alone. Teacher education needs more than relations with the many stakeholders in education: it needs partners, to come together with them, to keep together, and to work together. Teacher education should aim at establishing partnerships with other stakeholders in education, an argument supported by the Council of the European Union:

Teacher education programmes should draw on teachers' own experience and seek to foster cross-disciplinary and collaborative approaches, so that education institutions and teachers regard it as part of their task to work in cooperation with relevant stakeholders such as colleagues, parents and employers (The Council of the European Union, 2014/C 183/05).

In the following, partnership, as understood in this paper, will first be presented, followed by mutual benefits and challenges in partnerships with disciplines and institutions beyond the context of teacher education programs. Next, the sensitive subject of forming partnerships with students will be explored. The last part of the paper deals with partnerships between teacher education and the practice field and three models, illustrating three cases of schooluniversity partnerships. Partnerships enable teacher education to have a space where practice and theory meet to support students' preparation for the teaching profession, as well as to promote professional development for teachers and teacher educators. The aim of this paper is to argue that partnerships in teacher education need to go beyond rhetoric. 


\section{Partnerships - a working definition}

A search for the definition of partnership in the Online Etymology Dictionary indicates the Latin word for 'partner', partitionem, which means sharing, partition, division or distribution. By adding -ship (in Old English sciepe), which characterises a state or a condition of being, a current understanding of partnership as found in the on-line Merriam-Webster dictionary can be derived. Here partnership is defined as 'a relationship resembling a legal partnership and usually involving close cooperation between parties having specified and joint rights and responsibilities' (Merriam-Webster, author's emphasis added).

The working definition of partnerships in the current paper is that 'a partnership is an agreement between teacher education institutions and stakeholders of education who work together towards a shared goal, to improve education at all levels'. However, a definition consists of words only, and to put it into practice, some underlying conditions for sustainable partnerships should be familiar to and accepted by all parties.

If partnerships are to go beyond rhetoric and the partners strive to truly work together to achieve a shared goal, the challenges are multiple (Martin, Snow \& Franklin-Torrez, 2011), and it seems that some basic conditions ought to be in place. Inspired by Sandholtz (2002) some of the following conditions are likely to strengthen school-university partnerships. The partners should trust each other and be open to listening to and accepting different opinions and solutions. Magolda (2001) and Zeichner (2010) observe tensions that often develop in partnerships, and it is a challenge to work as a team which through negotiations seeks consensus to enable progress. Partners often represent two different cultures (Zeichner, 2010) yet for partnerships to be mutually beneficial, they draw on different kinds of expertise necessary to achieve the shared goal. Partners, therefore, should be open to and respect different forms of expertise, and also see value in it for the common interest. Likewise, partners often represent various types of organisations or institutions with different missions and limitations, however, instead of seeing differences as an obstacle to cooperation, it can be viewed as a benefit and provide opportunities for mutual learning (Sandholtz, 2002). Furthermore, a partnership involves risks, especially when the aim is to develop, to go beyond the comfort zone of all partners, and it can be time-consuming (Lemke \& Sebelli, 2008). The partners are likely to experience success as well as relapses, and it might be worthwhile to make explicit agreements about the sharing of power and responsibilities. Sandholtz (2002) expresses doubts regarding whether partnerships can function unless 
the partners plan for an ongoing commitment, especially in education where the achievement of goals are difficult to measure and might only be envisioned in a long term perspective.

In other words, educational partnerships that go beyond the rhetoric are based on long-term commitment and genuine aspiration to work together to improve education at all levels.

\section{Partnerships in teacher education}

Higher education institutions are commonly perceived to be the primary agent for preparing teachers and thus have the overall responsibility. This is, however, changing, and teacher education institutions are expected to establish partnerships with other stakeholders, as suggested in EU documents, such as Supporting Teacher Educators (2013) and Strengthening Teaching in Europe (2015). Both documents convey a clear call for cooperation. Furlong et al. (2000) and Darling-Hammond (2006) argue that teacher education needs to form strong relations with agents inside and outside academia, and especially on the practice field. It is argued in this paper that teacher education might be strengthened if teacher education institutions form partnerships with a number of stakeholders, as illustrated in Figure 1.

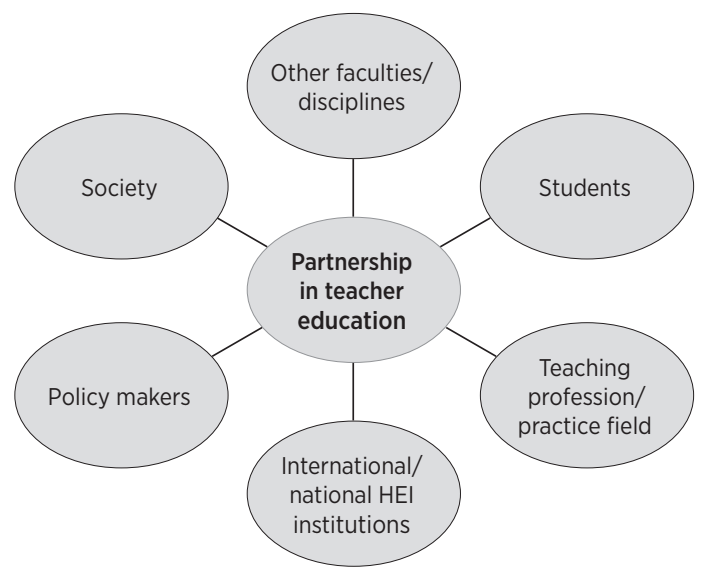

Figure 1. Partnerships in teacher education

In the following, the three partnerships emphasised in bold will be further developed. The first two, partnerships with other faculties and disciplines are briefly discussed, next partnership with students is attended to, before partnerships with the practice field are addressed in greater detail. Due to space 
concerns, possible partnerships with policy makers and society and partnerships crossing national borders are not dealt with in the current paper.

\section{Partnerships with other faculties and disciplines in higher education}

One of the main criticisms of teacher education is that it is fragmented (Darling-Hammond, 2006a, 2012; Grossman \& Hammerness, 2009). Students complain not only about the well-known gap between theory and practice but also between the various disciplines in teacher education, especially in secondary school teacher education, for which a high level of disciplinary expertise is required. Teacher education consists of four main components, disciplinary knowledge, knowledge about teaching the discipline (methodology), educational/pedagogical knowledge and practicum (Smith, 2015). Three decades ago, Shulman defined pedagogical content knowledge (PCK), which forms the core of teachers' professional knowledge (Shulman, 1986). However, the responsibility for the four components often lies with different faculties/departments in the university, and the dialogue between them is not always the best. Delicate issues are, for example, students' contact persons, scheduling, assignments and exams, and, in particular, where to place a lengthy practicum during a busy semester (Smith, 2015). At times it might even lead to a breakdown in communication, and the students find themselves in the middle of an internal institutional power relation struggle. Nevertheless, when having to react to an unplanned classroom situation, teachers are not likely to draw on knowledge learned in a specific component of teacher education for their in-action reflection (Schön, 1983). They make a decision based on how they read the complexity of the situation which probably reflects all four components. The Finnish researcher, Sven-Erik Hansén (2008) introduced the concept of 'teachership', which represents the comprehensive knowledge and actions of teaching; a question that needs to be asked is whether students experience that they are encouraged to develop 'teachership' during their education. For this to happen, faculties/departments which contribute to teacher education need to establish partnerships built on trust and respect for each other's expertise which might not always be the case. Brennan and Willis (2008, p. 297) claim that 'Education is not a top discipline in the university sector.

Another option for mutually beneficial learning lies in establishing partnerships between teacher education programs and other programs that educate for a profession, such as medicine, law, social workers, etc. They share a common goal, to educate professionals, and working in partnerships which explore the commonalities and distinctions in educating for a profession is a direction of research yet to be fully exploited. 


\section{Partnerships with student teachers}

Students of teaching not only form the largest group of agents in teacher education, but they are also the primary stakeholders of education. They are engaged in their professional education and will be those carrying the daily responsibility for preparing the coming generation of political leaders and contributing citizens. As early as in 1991, Michal Fullan asked: '[...] what might happen if we treated the students as someone whose opinion mattered" (Fullan, 1991, p. 170). Jean Ruddock (1999) asked what would happen "if we looked for an alternative approach to school improvement- through listening to and acting on what pupils have to say about learning in school" (Rudduck, 1999, p. 41). These voices from the end of the previous millennium talk about the benefits of forming partnerships with children in school, and even more so, similar ideas are to be considered in higher education and teacher education where the students are adults. Rudduck's question could be asked with some minor, yet important alterations; 'What would happen if we looked for an alternative approach to [teacher education] improvement through listening to and acting on what [students] have to say about learning [how to become a teacher]?' On the surface it might seem as if we have come much further in higher education as most universities have established student parliaments, students are represented on various academic committees, and students are also asked to assess the quality of teaching and the facilities in many institutions. The question is, though, to what extent do academia and teacher education programs listen to and act on the student teachers' voices?

Smith and Pollak (2008) examined how teacher educators in a large teacher education institution in Israel perceived the usefulness of standardised student evaluation on the quality of teaching. They found from the quantitative data that teacher educators accepted the democratic rights students have to provide feedback on the quality of teaching, as this was more or less a national norm in higher education. Entering into a deeper qualitative analysis of the data, teacher educators were much more apprehensive in their views, and they added comments such as 'What can they (the students) say about my teaching' (Smith \& Pollak, 2008, p. 203).

Cook-Sather (2002) claims that listening to student voices and paying attention to their suggestions when making decisions about education runs counter to political trends in education (she refers to the US context). She suggests there are two main obstacles to authorising student voices, or to forming genuine partnerships with students. First, there has to be a change in the structure of higher education, and students must become more involved in decisionmaking processes, and second, a change in perceptions, in the mindset, of how 
to form relations with the larger group of agents in education (i.e. the students). Historically, the power relations in higher education have been quite clear; the academy had the power, and the students were subject to how the power was executed. Today power relations have changed, and higher education institutions depend on the money students bring into the institutions either as tuition fees or as governmental funding depending on student numbers. Moreover, teacher education can be said to be 'under attack' from several directions, an increasing governmental investment (and not only financial) in higher education, demands by the public and private sector to educate according to their needs (Darling-Hammond \& Lieberman, 2012), as well as a strong call for a democratic education which also means, involving students in decision making (Josephson, 2016).

In the following, a practical suggestion of how to invite students to become partners in forming the content of teacher education is presented. The proposed example is influenced by Korthagen and his colleagues' work on Realistic Teacher Education (2001). The idea is that teacher education starts with a period of field observation, followed by the university courses. The curriculum is not pre-planned but formed in alignment with the students' experiences and questions from the practice field. Teacher educators, especially those involved with education and subject didactic modules do not finalise the lectures and the reading lists in advance but do so together with the students building on their cases and concerns. Later in the education process, the students spend a lengthy period in school, practicing teaching and being mentored by schoolbased teacher educators. At the teacher education institution, they share experiences and critical incidents in seminars with teacher educators, and once more, the practical experiences are explained by theory and supported by the relevant literature.

A schematic model of a practice-oriented teacher education is presented in Figure 2.

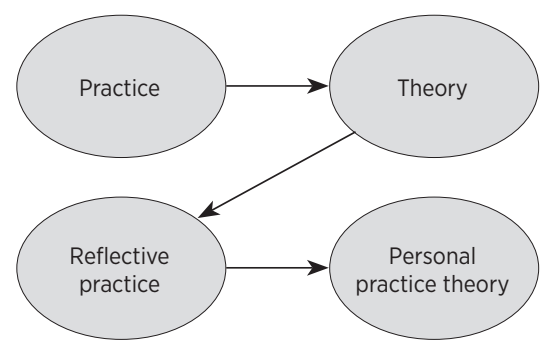

Figure 2. Practise-oriented teacher education 
At the beginning of their education, students of teaching are placed in schools to observe teaching, students, relationships, support systems, etc. without being familiar with the theoretical literature. Then they spend time at the university to become acquainted with relevant theory and empowered to reflect on and understand their experiences via a theoretical lens. However, as the teacher educators do not know in advance what stories the students will tell, they cannot pre-plan the lectures or reading lists. Instead of lectures, there will be more dialogic teaching including students, peers, and teacher educators. The content of the dialogues will lead to the suggested /compulsory reading of literature relevant to the issues raised. When the students next spend time in the practice field (this time, teaching), they have more content and theoretical knowledge which they draw on when engaging in reflective practice. The students do not merely accumulate experience; they are equipped with some basic theoretical knowledge to frame the analysis of the experiences. During this period, it is recommended that school-based mentors, teacher educators from the university, and the student teachers engage in professional dialogues about the practicum within what Kenneth Zeichner (2010) calls the third space:' [...] the creation of hybrid spaces in preservice teacher education programs that bring together school and university-based teacher educators and practitioner and academic knowledge in new ways to enhance the learning of prospective teachers' (Zeichner, 2010, p. 92).

The hypothesis is that further theoretical readings and discussions emerge from the joint meetings in the third space, addressing issues that have been raised by the students and school-based, as well as university-based teacher educators. Students and their experiences become the core of the teacher education program, and such an approach does not easily lend itself to topdown regulations of how and what to teach in teacher education. The approach also disputes the traditional view on education that the academy sits with the 'important' knowledge, and students are passive recipients of that knowledge. The main challenge with a more student-centred approach to teacher education is not only that it goes against traditions and perceptions about how to prepare teachers, but it also puts teacher educators in a vulnerable state. Such an approach would require teacher educators with a high level of professional knowledge, practical as well as theoretical, and confidence to engage in spontaneous teaching and to draw on knowledge relevant to unplanned stories and cases. Teacher educators will spend less time preparing lectures, but more time reading and reflecting on their own teaching and professional learning to enhance their students' learning. It is a question of exploiting what Helen Timperley (2011) calls 'teachable moments'. Another challenge for higher education 
institutions is that final reading lists can be presented only post-teaching and not prior to teaching. This requires a change of mind not only by teacher educators but also by academic leaders, as well as of students. The core issue is that teacher educators' professionalism needs to be trusted, so they are able to form true partnerships with students in how these are to be educated as teachers. The teacher education programs would be less uniform as every teacher educator in cooperation with the students would, to some degree, design the content of the course. The big question is whether there is space for such an approach in what we see as a more and more controlled higher education system in which efficiency and accountability are key words (Cochran-Smith, 2016). The Stanford Teacher Education Program (STEP) has, however, proved to be successful with a similar approach (Darling-Hammond, 2006b). Furthermore, are teacher educators prepared to take on this responsibility? A practice-oriented approach to teaching, as discussed above, is not only conditioned to partnerships with students but also partnerships with the practice field, which is elaborated below.

\section{Partnerships with the practice field}

Previously in this paper, the students as partners have been discussed, and their role in the third space, and in this section the role of the practice field and its actors is further elaborated. 'The overwhelming evidence of a decade of research on teacher knowledge is that knowledge of teaching is acquired and developed by the personal experience of teaching' (Munby, Russell \& Martin, 2001, p. 897). The arena for acquiring knowledge of teaching is the practice field, schools, whereas knowledge about teaching is mostly acquired at the university. The third space, as defined by Zeichner (2010) above, is the meeting point where the different aspects of teacher knowledge meet and merge, and the question is how the third space is structured and planned into the teacher education programme, and what the power relations between the various actors are. Bhabhas (1990) uses the term 'hybrid spaces' when two cultures with different traditions and perceptions meet and through communication and negotiations new understandings emerge, and a hybrid third space is created. This is what a true partnership between teacher education institutions and the practice field might lead to, and actors from both cultures will cross boundaries and develop new understandings.

In many countries, teacher education is mainly understood as pre-service or initial education for teaching. However, today a broader understanding of the concept is emerging: that teacher education is career long. It starts with initial education and continuous throughout the induction period and the in-service education of teachers. The Teaching Council in Ireland (2011) has 
argued in favour of revisiting the concept of teacher education, and to take this into consideration in allocating resources to professional education. Similar ideas are articulated by the European Commission (2013), 'Teacher educators are not only responsible for the initial education of new teachers but also contribute to the continuing professional development of Europe's six million serving teachers. They are present at every stage of the teacher's career' (European Commission, 2013, pp. 6-7). The importance of the continuous professional development of teachers is argued for by several authors (see van den Bergh, Ros \& Beijaard, 2015). Moreover, teacher education is a career-long education that involves teacher educators in higher education as well as school-based teacher educators at every stage of the teacher's career. A central component of initial teacher education is the practicum, followed by an induction phase. Research suggests that school-based mentoring for novices has a positive effect on motivation, resilience, and retention in teaching (Fresco \& Nasser-Abu Alhija, 2015; Ingersoll \& Perda, 2012). In-service learning of teaching takes place, to a large extent, in schools; it is work-based learning (Eraut, 2014). However, attending formal courses offered by higher education institutions might be useful to update professional knowledge. In the emerging conception of teacher education as continuous education, the practice field and higher education share the responsibility for teacher education, they are partners pursuing the same goal, educating teachers to improve education at all levels. The question is, however, if they form true partnerships in which they are equal partners, or are there hidden power-struggles, for example, of who leads the partnership, who shall decide on the content of practicum or assessment of student teachers' performances, which are not often articulated or discussed? Do the higher education actors respect the expertise held by the practice field as being equal to their own theoretical expertise and vice versa? The literature reveals that this is not always the case, and tensions are found to be common (Bullough \& Draper, 2004; Halvorsen, 2014; Magolda, 2001; Zeichner, 2010).

In a doctoral dissertation, an extensive study of partnerships between teacher education and the practice field of early childhood, elementary school, and upper secondary school, Halvorsen (2014) found four different resources which support the development of true partnerships in the meeting of challenges. Halvorsen (2014) has termed these intentionality, unpredictability, flexibility, and vitality.

Intentionality: In a partnership, the actors come with different expectations, and there is often a concern for how to protect their own identity and autonomy. A strong intention of pursuing a shared goal is needed to overcome tensions and concerns, and when this happens, Halvorsen (2014) found that the 
relations in the partnership became more democratic. When the intention was weak, often in situations where the agents had been forced into a partnership, tensions and power struggles characterised the collaboration, and a true partnership was not established: it existed only on the level of rhetoric.

Unpredictability: When working in collaboration with others, unexpected occurrences are likely to develop. If such situations are seen as problems and the blame is put on one of the partners, there is little hope for future productivity of that partnership. However, if the unexpected occurrences are experienced as challenges, and there is mutual trust among the partners that the challenge can be solved and used as a learning experience, then unpredictability was found to strengthen the internal relations in the partnership.

Flexibility: Various partners join partnerships for diverse reasons, and they come with substantial perceptions and habits of how to work. In Halvorsen's study (2014), she found that when the limits of tolerance founded on habits and rituals could be liberated in imaginary contexts that were different from the familiar context, freedom and new ideas then catalysed innovation. It depended on the level of flexibility that the partners showed to go beyond their own comfort zone and face unfamiliar situations and contexts. In cases in which this kind of flexibility was missing, the partnerships did not develop beyond a formal agreement.

Vitality: When concerns about how to position yourself in a partnership, especially in relation to maintaining autonomy, yet remaining integrated in the partnership, are overcome, then curiosity for how the collaboration develops and how it might benefit a shared goal might catalyse vitality of the partnership and enhance sustained engagement and creativity (Halvorsen, 2014).

Below, three cases of relationships between the practice field and higher education are described; however, not all meet the conditions for partnerships discussed in the current paper. The continuum illustrates the level of commitment of the three types, practice schools, partner schools and university schools:

\begin{tabular}{|lc|}
\hline Practice schools & Partner schools \\
\hline SEPARATED & University schools \\
\hline
\end{tabular}

Figure 3. School-university relationship

\section{Practice schools}

In the Norwegian context, universities assign students to schools for practice teaching, and there is a clear division between responsibilities between 
the school and the university. The university is responsible for teaching the theory, and the schools deal with the practical skills of teaching. A third learning space is not developed; there are two separate learning arenas for the students. In the practice schools, the students are mentored by teachers, school-based teacher educators, who are not required to have any form of mentor education. The communication between the university and the school is mainly written, and there are few face-to-face meeting points other than, perhaps, a pre-practicum information meeting. A university-based teacher educator visits the student teachers to observe what students often call 'an examination lesson', not always a perception shared by the visiting teacher educator (personal experience as head of teacher education in a Norwegian university). However, the final assessment of the practicum, if the student has passed or failed, is likely to lie with the university teacher educator, in consultation with the written report from the school. It is often the university or the government that decides the length of the practicum, the number of lessons to be taught, the focus of assessment, and the practice field that holds the practical expertise is not always consulted. This kind of relationship between the practice field and higher education cannot be characterised as a true partnership with shared responsibilities and rights, and mutual trust in each other's expertise. The power lies with higher education, and the school provides services with or without reimbursement.

\section{Partner schools}

The case of what is called 'partner schools' is also from Norway and is initiated when the university sends out a call to schools to apply to become partner schools. Schools have to present their qualifications, such as the number of educated mentors, innovative projects, and to write a brief statement about wanting to work closely with the university. The main objective is that the schools shall be a good arena for the students' practicum. The school principal commits the school to accepting a certain number of student teachers during the partnership period and to allow for a number of teachers per year to attend the credited mentor education program offered by the university. The university offers mentor education, which provides academic credits if the mentor wants to pursue education at a master level. Teacher educators from the university are available for lectures and seminars in the partner schools, and the university organises a two-day seminar for the school principals and the coordinating mentors every year. The schools are also used as contexts for research and development $(\mathrm{R} \& \mathrm{D})$ projects under the aegis of the university. The partnership contract is for three years, at the end of which a new call is sent out to schools. The 'old' partner schools can re-apply, but they are not guaranteed 
acceptance, which means there is an opening for new schools to be involved (University of Bergen, 2015).

This model better resembles a partnership model than the previously discussed practice school model does. There are mutual commitments reflecting various expertise, and there are also multiple meeting points between school-based and university-based teacher educators. They get to know each other, and there are opportunities for developing an understanding of how to achieve the shared goal, developing a better school to improve student learning. When evaluating nearly five years of such a partner school model, the school principals were pleased with the project and said they noticed a positive change in the school (Smith et al., 2010). The school as a whole became more attentive to its own practice, and the dialogue with the university gave them a different perception of how the school and university complimented each other in educating teachers at all three phases of teacher education. However, when all teachers in the school, including those who had not been mentors, were asked about how they had experienced the partnership, it turned out that in some schools they were not even aware that the school was in a partnership with the university (Smith et al., 2010). Moreover, it was still the university that 'owned' the partnership, provided the resources, decided which schools were selected as partners, and had the responsibility for the final assessment of the practicum. The third space of mutual learning of students, school-based and universitybased teacher educators, was not formed, and it was still the university which 'taught' the other actors.

\section{University schools}

The basic idea behind university schools in Norway is that selected schools have the same status as university hospitals. Learning takes place in both arenas, and the involved actors have dual positions in the university school as well as at the university. $R \& D$ projects involve researchers in both contexts, and jointly they pilot new approaches to teaching and teacher education, and there is shared responsibility for resources needed for the joint activities. The concept of university schools takes on different understandings in various contexts. In England, much of the initial teacher education (ITE) is placed in schools, and the universities are obliged to engage in partnerships with schools. Schools do not have to engage in partnership with the university providers of ITE (Taylor, 2008). All schools that are involved in teacher education are called 'university schools' in England. Taylor (2008) acknowledging that compulsory partnerships are diverse (Furlong, Whitty \& Whiting, 1996), found in the context of his study, a case of university-school partnership, that: 
Partnership is perceived as an experience between the two environments joined by the students. While university teacher educators and mentors interact, there is awareness that the university has less direct contact with (and thus control over) the students, and school experience is viewed as the most valuable experience (Taylor, 2008, 78).

In Norway, the university school is an emerging concept, and three main universities have developed various models, but with some central concepts. The University of Oslo (UoO) and the University of Tromsø/ The Arctic University of Norway (UoT) have formed a partnership with the Centre for Professional Learning in Teacher Education (ProTED) which strives to develop a 'future-oriented knowledge-based teacher education'. Working closely with the practice field is part of the vision, and they have developed a university school model. In the model, there is close collaboration between students, practitioners, and researchers (ProTed Centre for Professional Learning in Teacher Education, 2016), and in Tromsø, also with the municipality. The University of Oslo has 20 partner schools (UoO, Institute for Teacher Education and School Development, 2016), whereas UoT has selected eight schools as university schools in cooperation with the municipality. The four core principles of this kind of partnership are developing the practicum, R\&D projects, competence development of teachers and teacher educators, and establishing networks to disseminate the experiences from the project (University of Tromsø /The Arctic University of Norway, 2016). A major factor for both universities is the inclusion of dialogue seminars in the respective teacher education programmes. It is a day where university teacher educators, both pedagogues, and subject didactitians meet with mentors and students to discuss cases and experiences from the practicum in a community of learning. This is a way of operationalising Zeichner's (2010) concept of the third space in teacher education. The dialogue seminar is still in a beginning phase, and there is understandably much work to do to improve it; for example, that university teacher educators see the benefits of the seminar and actively participate. The concept of dialogue seminars is, however, a promising initiative.

The largest university in Norway, the Norwegian University of Science and Technology (NTNU) in Trondheim launched its university school project in August 2015. The project is a partnership with the regional county and the municipality, which selected the two university schools. NTNU's model differs from that of UoO and UoT: only two schools are involved, and it is more in line with the perception of university hospitals. Whereas the main aim of the model developed in Oslo and Tromsø is to improve teacher education, NTNU, and its 
partners have placed the motivation and learning of students in schools at the centre, and innovative approaches to school teaching shall be tried out within a safe context. School development and empowerment of teachers are major aspects of the model, alongside strengthening teacher education, which endeavours to integrate subject knowledge, educational and didactical knowledge and practical skills. In other words, it is a serious attempt to reduce students' experience of fragmentation in teacher education. R\&D projects are contextualised in schools as well as in teacher education. It is a stated aim of NTNU's university school project that it shall be a win-win project for all partners and that schools and the university need to draw on each other's expertise for development to take place (Norwegian University of Science and Technology, 2016). The partnership between the university, authorities, and schools in Trondheim is being formed as it is being put into practice, and there is still a long way to go. Thus far, eight teachers from schools have been given a part-time teaching and coordinating position at the university; four school teachers have been offered doctoral scholarships funded by the authorities and the university. Furthermore, all teachers in one school and a third of the teachers in the second school have started their mentor education. The study program is developed jointly by the schools and the university. The head of the project comes from the practice field, and she shares her time between the university and the two schools. Knowledge developed in the project will be disseminated to other schools in the area and beyond, as well as to the academic community. The project started less than a year ago, and it is too early to discuss results; nevertheless, it will be interesting to follow this university school project in the future.

Partnerships in the form of university schools in Norway are a new initiative, and much research is needed to examine whether they fulfil their worthy aims, and what impact they have on education generally and teacher education specifically. The various models described above illustrate possible variations in school-university cooperation. Caution should be made that these are not research-based models; they merely describe current practices in Norway. Future extensive research is needed to document the outcome of the university school projects.

Going back to the working definition of partnerships at the beginning of the paper, that partnerships are built on mutual respect and acknowledgment of diverse expertise, it seems that only the university school models will be on the right side of the continuum presented in Figure 3. The fact that the authorities are involved as partners in some cases is encouraging, especially in relation to resources, commitment, and sustainability. The partnerships do not depend on specific persons but on a shared vision of how to improve education. 


\section{Conclusion}

The main argument in this discussion paper has been that teacher education is in need of developing partnerships with other stakeholders in education that goes beyond rhetoric. However, true partnerships can only develop under certain conditions, such as developing a shared vision, commitment, and mutual respect for each other's expertise (Halvorsen, 2014; Sandholtz, 2002). März and Kelchtermans (2013) argue that when introducing changes in education, it is not only the wider policies that form the implementation of the change but to a large extent also the internal politics, meaning the micro-politics of the immediate context. In a partnership, there are various levels of micro-politics involved: those internal to each partner and those internal to the partnership. Thus, power struggles are likely to emerge. Traditionally, the university has been the decisive voice in collaborations with stakeholders of education, but this view seems now to be challenged, by students as well as by the practice field. A conceptual change has to take place among all stakeholders if teacher education is interested in developing partnerships that go beyond rhetoric.

This paper has discussed how teacher education can be strengthened by forming true partnerships among the various contributors to teacher education, other professions, the students and the practice field. This is, as argued in this paper, a limited representation of the range of partnerships in teacher education. Stakeholders of education are also politicians, society, including parents, and in today's globalised world, also education providers beyond national borders. Space did not allow for further elaboration on the wider range of partnerships teacher education institutions could and should initiate and maintain. However, currently it seems to be more than enough to exploit the possibilities for going beyond the rhetoric in establishing partnership within the near context of teacher education.

\section{References}

Bhabha, H. (1990). The third space. In J. Rutherford (Ed.), Identity, community, culture and difference (pp. 207-221). London: Lawrence and Wishart.

Brennan, M., \& Willis, S. (2008). Sites of contestation over teacher education in Australia. Teachers and Teaching: Theory and Practice, 14(4), 295-306. Special Issue: Politics and policy in teacher education, International Perspectives.

Bullough, R. V., \& Draper, R. J. (2004). Making sense of the failed triad: Mentors, university supervisors and positioning theory. Journal of Teacher Education, 55(5), 407-420.

Centre for Professional Learning in Teacher Education (ProTed). (2016). Retrieved 25.03.2016 from 
http://www.uv.uio.no/proted/english/.

Cochran-Smith, M. (2016). Teacher Education Reform in the U.S.: Where's the Field Turning?

Presentation for AERA Division K Symposium Policy, Governance and Quality in Teacher Education Systems: Four Cases, 10.04.2016, Washington, DC.

Cook-Sather, A. (2002). Authorizing students' perspectives: Toward trust, dialogue, and change in education. Educational Researcher, 31(4), 3-14.

Council of European Union. (2014). Council conclusions of 20.05.2014 on effective teacher education

(1) 2014/C 183/05. Retrieved 22.11.2015 from http://eur-lex.europa.eu/legal-content/EN/TXT/?uri=OJ \%3AJOC_2014_183_R_0005.

Darling-Hammond, L. (2006a). Constructing 21st-Century Teacher Education, Journal of Teacher

Education, 57(3), 300-314.

Darling-Hammond, L. (2006b). Assessing teacher education the usefulness of multiple measures for assessing program outcomes. Journal of Teacher Education, 57(2), 120-138.

Darling-Hammond, L. (2012). Powerful Teacher Education: Lessons from Exemplary Programs. New Jersey: John Wiley and Sons.

Darling-Hammond, L., \& Lieberman, A. (Eds.) (2012). Teacher Education Around the

World. London: Routledge.

Donaldson, G. (2011). Teaching Scotland's future: Report of a review of teacher education in Scotland.

Edinburgh, Scotland: Scottish Government.

Donaldson, G. (2015). Successful futures: independent review of curriculum and assessment arrangements in Wales: OGL. Retrieved 27.03.2016 from http://gov.wales/docs/dcells/

publications/150317-successful-futures-en.pdf.

Eraut, M. (2014). Developing Knowledge for qualified professionals. In O. McNamara, J. Murray, \&

M. Jones (Eds.), Workplace Learning in Teacher Education (pp. 47-72). Dochdrecht: Springer.

European Commission (2013). Supporting Teacher Educators for Better Learning Outcomes.

European Commission (2015). Strengthening teaching in Europe.

Fresko, B., \& Nasser-Abu Alhija, F. (2015). Induction seminars as professional learning communities for beginning teachers. Asia-Pacific Journal of Teacher Education, 43(1), 36-48.

Fullan, M. (1991). The New Meaning of Educational Change. New York, NY: Teachers' College Press. Furlong, J., Barton, L., Miles, S., Whiting, C., \& Whitty G. (2000). Teacher education in transitionRe-forming professionalism? Buckingham / Philadelphia: Open University Press.

Furlong, J., Whitty, G., \& Whiting, C. (1996) Re-defining partnership: revolution or reform in ITE. Journal of Teacher Education, 22(1), 34-57.

Grossman, P. \& Hammerness, K. (2009). Redefining teaching- re-imagining teacher education.

Teachers and Teaching: theory and practice, 15(2), 273-289.

Halvorsen, K. (2014). Partnerships in Teacher Education. (Doctoral thesis). Bergen: University of Bergen.

Hansén, S. E. (2008). Rapport från den koordinerande programsensorn för lärarutbildningen vid Universitetet i Bergen. [Report from the external examiner of teacher education at the University of 
Bergen]. Bergen: University of Bergen.

Ikpeze, C. H., Broikou, K. A., Hildenbrand, S., \& Gladstone-Brown, W. (2012). PDS Collaboration as Third Space: An analysis of the quality of learning experiences in a PDS partnership. Studying Teacher Education, 8(3), 275-288.

Ingersoll, R., \& Perda, D. (2012). How high is teacher turnover and is it a problem? Philadelphia, PA:

Consortium for Policy Research in Education, University of Pennsylvania.

Josephson, J. (2016). Democracy and Higher Education. Paper presented at Annual Conference of the Southern Political Science Association (87th), San Juan (P.R.). Retrieved 27.06.2016 from http:// dx.doi.org/doi:10.7282/T3 $\mathrm{KW}_{5} \mathrm{~J}_{3} 6$.

Korthagen, F. A. J. (2001). Linking Practice and Theory - The Pedagogy of Realistic Teacher Education.

Mahwah, New Jersey: Lawrence Erlbaum Associates, Publishers.

Lemke, J. L., \& Sabelli, N.H. (2008). Complex systems and educational change: towards a new research agenda. Educational Philosophy and Theory, 4o(1),118-129.

Magolda, P. (2001). Border Crossings: Collaboration Struggles in Education. Journal of Educational Research, 94(6), 346-358.

Martin, S. D., Snow, J. L., \& Franklin Torrez, G. A. (2011). Navigating the Terrain of Third Space: Tensions With/In Relationships in School-University Partnerships. Journal of Teacher Education, 62(3) 299-311.

März,V., \& Kelchtermans, K. (2013). Sense-making and structure in teachers' reception of educational reform. A case study on statistics in the mathematics curriculum, Teaching and Teacher Education, $29,13-24$.

Munby, H., Russell, T., \& Martin, A. K. (2001). Teachers' knowledge and how it develops. In V. Richardson (Ed.), Handbook of research on teaching (4th ed., pp. 877-904). Washington, DC:

American Educational Research Association.

Norwegian University of Science and Technology (NTNU). (2016). University Schools. Retrieved 25.03.2016 from https://www.ntnu.edu/school-university-partnership.

OECD (2005). Teachers Matter. Attracting, Developing and Retaining Effective Teachers. Paris: OECD. Rudduck, J. (1999). Teacher practice and the student voice. In M. Lang, J. Olson, H. Hansen, \& W. Bunder (Eds.), Changing Schools/Changing Practices: perspectives on educational reform and teacher professionalism (pp. 41-54), Louvain: Graant.

Sandholtz, J.H. (2002). Inservice training or professional development: contrasting opportunities in a school/university partnership. Teaching and Teacher Education, 18(7), 815-830.

Schön, D. A. (1983). The reflective practitioner: How professionals think in action. New York: Basic Books.

Shulman, L. S. (1986). Those who understand: Knowledge growth in teaching. Educational Researcher, 15(2), 4-14.

Smith, K., \& Welicker-Pollak, M. (2008). What can they say about my teaching? Teacher educators' attitudes to standardised student evaluation of teaching. European Journal of Teacher Education, $31(2), 203-214$. 
Smith, K. (2015). The Act of Diplomacy: Looking back at the position as the Head of teacher education. In R. Clift, J. Loughran, G. Mills, \& C. Craig (Eds.), Inside the Role of the Dean. International perspectives on leading in higher education (pp. 132-146). London-New York: RoutledgeTaylor Francis Group.

Smith, K., Hjertager Lund, H., Krumsvik, R., Steen, O. I., Vedvik Tonning, A. S., Ulvik, M., \& Olsen, J.I. (2010). Pilotering av UiB sin partnerskolemodell. (Piloting a Partnership Model at UoB). Final report. Bergen: University of Bergen.

Taylor, A. (2008). Developing understanding about learning to teach in a university - schools partnership in England. British Educational Research Journal, 34(1), 63-90.

The Teaching Council, Ireland (2011). Policy on the Continuum of Teacher Education. Dublin: The Teaching Council.

Timperley, H. (2011). The Power of professional learning, New York: Mc raw - Hill / Open University Press.

University of Bergen (2015). Partnerskolesamarbeid (Partner School Cooperation). Retrieved 24.03.2016 from http://www.uib.no/utdanning/laerer/49235/partnerskolesamarbeid.

University of Oslo, Institute for Teacher Education and School Development. Retrieved 26.03.2016 from http://www.uv.uio.no/ils/forskning/prosjekter/universitetsskoleprosjektet/.

University of Tromsø The Arctic University of Norway. Retrieved 26.03.2016 from https://uit.no/ prosjekter/prosjekt?p_document_id=288271.

van den Bergh, L., Ros, A., \& Beijaard, D. (2015). Teacher learning in the context of a continuing professional development programme: A case study. Teaching and Teacher Education, 47, 142-150. Zeichner, K. (2010). Rethinking the connections between campus courses and field experiences in college- and university-based education. Journal of Teacher Education, 61(1-2), 89-99.

\section{Biographical note}

Kari Smith, Professor (Ph.D.) Programme for Teacher Education (PLU), Norwegian University of Science and Technology (NTNU). Smith's main research interests are teacher education, professional development, mentoring novice teachers and assessment for and of learning. She has acted as the Head of Teacher Education programs abroad as well as at the University of Bergen, Norway. Currently she is the Head of the Norwegian National Research School in Teacher Education (NAFOL). Professor Smith has published widely and has given invited talks in Australia, New Zealand, China, Dubai, Korea, Singapore, Africa, USA, South America, Europe, Israel, and in her own country, Norway. 